\title{
QUEEN'S
UNIVERSITY
BELFAST
}

\section{Tenure-track contract helps self-selection}

Popov, S. (2015). Tenure-track contract helps self-selection. Economics Bulletin, 35(4), 2482-2486.

http://www.accessecon.com/Pubs/EB/2015/Volume35/EB-15-V35-I4-P249.pdf

\author{
Published in: \\ Economics Bulletin
}

Document Version:

Publisher's PDF, also known as Version of record

Queen's University Belfast - Research Portal:

Link to publication record in Queen's University Belfast Research Portal

Publisher rights

(C) 2015 Economics Bulletin

\section{General rights}

Copyright for the publications made accessible via the Queen's University Belfast Research Portal is retained by the author(s) and / or other copyright owners and it is a condition of accessing these publications that users recognise and abide by the legal requirements associated with these rights.

Take down policy

The Research Portal is Queen's institutional repository that provides access to Queen's research output. Every effort has been made to ensure that content in the Research Portal does not infringe any person's rights, or applicable UK laws. If you discover content in the Research Portal that you believe breaches copyright or violates any law, please contact openaccess@qub.ac.uk. 


\title{
$\mathbb{A}$ Economics Bulletin
}

\section{Volume 35, Issue 4}

\section{Tenure-track contract helps self-selection}

\author{
Sergey V. Popov \\ Queen"s University Belfast
}

\begin{abstract}
Tenure-track contract is criticized for curbing the incentives to expend effort after obtaining tenured status. Yet the most productive faculties seem to work on a tenure contract, and schools which aim to employ the best faculty seem to prefer to offer tenure-track contracts to their new recruits. I argue that tenure-track contracts are by construction more attractive to more able freshly minted PhDs, and therefore the observed sorting is rationalizable.
\end{abstract}

I'd like to thank Dilijan Training and Research Centre of the Central Bank of Armenia for their hospitality during my stay when this paper was written. The usual disclaimer applies.

Citation: Sergey V. Popov, (2015) "Tenure-track contract helps self-selection", Economics Bulletin, Volume 35, Issue 4, pages $2482-2486$ Contact: Sergey V. Popov - s.popov@qub.ac.uk.

Submitted: June 08, 2015. Published: November 21, 2015. 


\section{Introduction}

Machlup (1964) describes four different types of tenure, starting from tenure by law and ending with tenure by courtesy, kindness, timidity or inertia. Some schools do not offer tenure contracts, but they act towards their faculty as if they had a tenure contract, and one can easily name an example of an underperforming faculty member in a non-tenure school who is certainly not getting fired. The question is, therefore: why do schools impose on themselves the burden of a tenure contract instead of merely acting as if they did?

Tenure by contract, unlike tenure by kindness, requires having a tenure-track position. The path from tenure-track to tenure is not the same as the path from the non-tenure-track 1 to entrenchment because the evaluation of the tenure-track contract is independent of the current job market situation. For instance, many more people take part in evaluating a tenure candidate, from the top brass of the home university to reference writers from outside the department, who try to establish whether the candidate satisfies the school's standards. The lecturer, however, can be replaced by a better-performing outsider; so the decision of whether to keep the lecturer has a noisier threshold. In this paper, I show that a riskneutral freshly minted PhD of high ability, when choosing between a tenure-track contract and a lecturer contract, effectively behaves as a risk-averse individual, and prefers the former; whereas the $\mathrm{PhD}$ of low ability behaves as a risk-lover, and prefers the lecturer contract.

This explanation complements other economic arguments for tenure. For instance, Alchian (1953) reasons that permanent employment might translate into lower salaries, lowering the faculty costs for the university and for society. Carmichael (1988) argues that the nontenured faculty, not willing to nurture competition, will underreport the ability of talented incomers. McPherson and Winston (1983) argues that the narrow specialization of professors in cases of free hiring and firing will require too much costly turnover compared to less specialized industry. Brown (1997) reasons that tenure is natural to academic institutions because academics are the residual claimants of the university's product (see his paper for a historical overview of development of the US education system). ${ }^{2}$ All these reasons take the faculty body as fixed and given; my argument, however, is based on the change in the ability distribution of the incoming faculty.

These economic reasons complement AAUP's Statement of Principles of 1940, which outlined the tenure system to protect the faculty's academic freedom (Ginsberg (2011) provides some excellent popular reading in the history of academic freedom abuse), but Ceci et al. (2006) empirically questions the efficiency of the tenure system in this regard. Nevertheless, Premeaux (2012) finds universal support for the tenure system in US business schools ${ }^{3}$ Criticism of the tenure system is abundant: other things being equal, administrators would like to have more rights to create more incentives for the professors. The contribution of this

\footnotetext{
${ }^{1}$ In the US, these are usually called adjunct professors or lecturers; in UK, they are called teaching fellows. Hereafter, we will refer to these contracts as lecturers' contracts.

${ }_{2}^{2}$ Cater et al. (2015) surveys more recent papers for the interested reader, and argues that tenure contracts make sense if students value a faculty's past accomplishments.

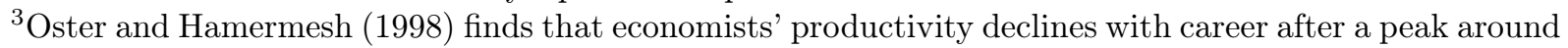
the usual tenure decision time, but does not attribute this to tenure incentives. Jones et al. (2014) finds that the peaking occurs for Nobel prize winners and inventors, too, which makes the tenure decision an unlikely driver.
} 
paper is to show that, in using the tenure-track contract, administrators create incentives for the right job market candidates to manifest themselves by their choice of the right up-or-out contract 4 .

\section{The Problem of a Freshly Minted PhD}

Consider a problem of a freshly graduated $\mathrm{PhD}$ (hereafter $\mathrm{AP}$ ) who chooses between two offers. AP has an innate ability $\theta$, and after 6 years of employment, he will be able to demonstrate a signal of his ability $q=\theta+\varepsilon$, where $\varepsilon$ is distributed with a pdf $f(\cdot)$, continuous and positive on $\mathbb{R}$, and a cdf $F(\cdot)$. AP chooses between offers from two schools and an outside opportunity, which provides a lifetime utility $\bar{u}$. At the moment of choice, AP knows his $\theta$, but not his $\varepsilon$. The time discount factor to compare the payoff today with a payoff in 6 years is $\delta$. Let the utility of being a faculty member during the probation period be $\gamma$. AP is risk-neutral.

SCHOOL 1 offers a tenure-track contract. After 6 years, AP will be evaluated: if his signal $q$ is above $\hat{q}$, he will get promoted to a professorial position (the lifetime utility of which is normalized to 1), and otherwise his only option is the outside opportunity $\bar{u}<1$.

Therefore, the utility from choosing the offer from School 1 is

$$
U_{1}(\theta)=\gamma+\delta \overbrace{(1-F(\hat{q}-\theta))}^{\text {pass tenure review }}+\underbrace{F(\hat{q}-\theta)}_{\text {fail tenure review }}[\delta \bar{u}]=\gamma+\delta-\delta[1-\bar{u}] F(\hat{q}-\theta) .
$$

SCHOOL 2 offers a lecturer contract that does not have a tenure-track confirmation rule. In 6 years, the school may encounter an alternative employee (from a different school, for instance) whose signal of quality is $\tilde{q}$. If $q<\tilde{q}$, the school sacks the AP, and hires another worker instead. The AP then will enjoy the outside opportunity $\bar{u}$. If the alternative employee is not as good $(q \geq \tilde{q})$, the AP gets promoted to a professorial position (utility of which is 1 ), which is not challenged by outsiders because of the entrenchment. The random variable $q_{2}$ is distributed on $[\underline{q}, \bar{q}]$. The utility from the offer of School 2 is therefore

$$
U_{2}(\theta)=E_{\tilde{q}}[\gamma+\delta \overbrace{(1-F(\tilde{q}-\theta))}^{\text {AP beats challenger }}+\underbrace{F(\tilde{q}-\theta)}_{\text {Challenger beats AP }}[\delta \bar{u}]]=\gamma+\delta-\delta[1-\bar{u}] E_{\tilde{q}} F(\tilde{q}-\theta) .
$$

I assume that all monetary payoffs in both schools are identical to be sure that all the differences in the preferences of the AP are driven solely by the contract structure.

\footnotetext{
${ }^{4}$ These contracts are not specific to the Economics profession. Kahn and Huberman (1988) suggests that this is a device for stimulating firm-specific investments. Waldman (1990) proposes a signalling model of an up-or-out contract. I remain agnostic about the reasons why up-or-out contracts are used in academia, and employ the common knowledge that most contracts in the Economics academic job market have the up-or-out feature.
} 


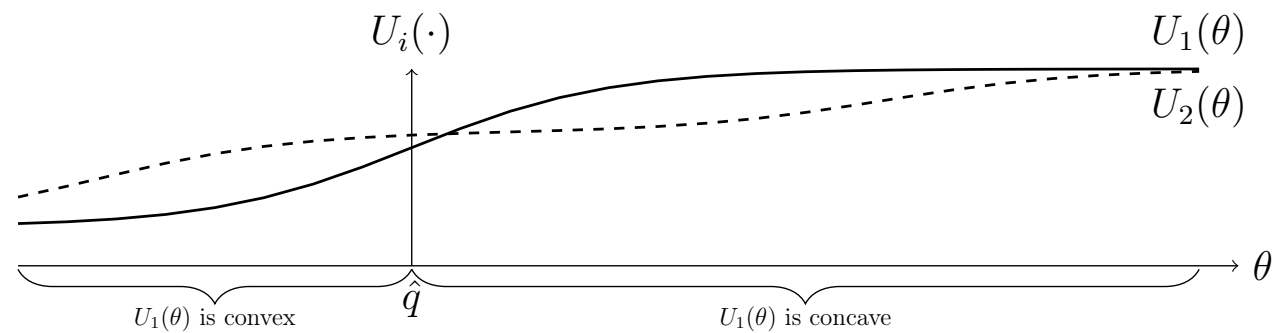

Note: the density in the picture is single-peaked, with peak at $0: f^{\prime}(0)=0$. This allows more precise characterization to be made of the areas discussed in Proposition 1: for $\theta>2 \hat{q}-\underline{q}$, $U_{1}(\theta)>U_{2}(\theta)$, and the reverse holds for $\theta<2 \hat{q}-\bar{q}$.

Figure 1: The Utility of the AP

Proposition 1. When $E[\tilde{q}]=\hat{q}$, high $\theta$ APs prefer School 1, whereas low $\theta$ APs prefer school 2.

Proof. Function $f(x)$, to be a proper pdf, has to increase for small $x$ and decrease for large $x$ to integrate to 1 while being positive. Because of this:

- When $\theta$ is high enough, function $-F(\hat{q}-\theta)$ is concave in the relevant region, and by Jensen's inequality, $-F(\hat{q}-\theta)=-F\left(E_{\tilde{q}}[\tilde{q}]-\theta\right)>E_{\tilde{q}}[-F(\tilde{q}-\theta)]$.

- When $\theta$ is low enough, function $-F(\hat{q}-\theta)$ is convex in the relevant region, and by Jensen's inequality, $-F(\hat{q}-\theta)=-F\left(E_{\tilde{q}}[\tilde{q}]-\theta\right)<E_{\tilde{q}}[-F(\tilde{q}-\theta)]$.

Picking a $\theta$ large (small) enough to be sure that the whole support of $\tilde{q},[q, \bar{q}]$, is inside the concave (convex) zone of $-F(\hat{q}-\theta)$ finishes the proof.

The intuition of this Proposition is straightforward. When the best APs know that their threshold is fixed, it is easier for them to be sure that they will pass the threshold, while less able APs know the chances of tenure are slim for them, and they choose the lecturer contract hoping that no one more able will challenge their employment. The noisiness of the threshold increases both Type I and Type II errors. Able APs suffer because of an increased Type II error; less able authors benefit because of an increased Type I error. This Proposition also supplies an intuition why it is extremely hard to move from being a lecturer to a tenure-track job: if a person had agreed already to be a lecturer while clearly being able to secure a tenure-track position in a similar school, they has already signalled their belief in their own inferior ability.

Robustness More frequent challenges to the lecturer's contract, as well as additional challenges after 6 years of service, will increase the riskiness of that contract, making it less attractive for able APs. The interim evaluations of the lecturer's ability will be even noisier: indeed, if an interim evaluation is less noisy, the administration can use this interim evaluation signal instead of the signal in 6 years' time. Were the threshold in School 1 higher than the average threshold in School 2, the envelope theorem would predict that School 1 would become less attractive for all AP types; but since the marginal (dis)utility of higher threshold is proportional to $f(\cdot)$, most- and least-able authors are least affected by that change. 
The payoff from the lecturer's job being identical in all aspects, such as $\gamma$ and $\bar{u}$, to the payoff from the tenure-track job is needed to make contrast more evident (in fact, in some countries university administration has limited control over the salary of faculty members). Obviously, if the job yields smaller payoff, it's going to be less attractive, and lower demands for tenure, other things being equal, will make the job more attractive. If, after failing tenure review, the AP can still try for a post as a lecturer, the utility of being on a tenure-track job is weakly higher; if the AP can use both offers sequentially, he is first going to use the one with higher utility from the scenario of Proposition 1.

The assumption that the challengers' abilities come from a bounded support goes against the spirit of the proof of Proposition 1. Indeed, one would naturally assume that the AP who makes a decision must have his ability $\theta \in[q, \hat{q}]$. This makes it hard to posit $\theta$ high enough so ensure that the whole interval of possible thresholds is in the concave portion of the utility function. However, after grasping Proposition 1, one can immediately see that if the distribution of challengers' abilities comes from a mix of a bounded support distribution ("the usual contenders") and an unbounded support distribution ("the unusual contenders"), the ordering of $U_{1}(\theta)$ and $U_{2}(\theta)$ has to remain the same if the share of the unbounded support distribution is not too large. AP in question might as well be an unusual contender!

Policy ImPliCATIONS Banning tenure, á la Margaret Thatcher's 1987 policy, will prevent universities from offering tenure-track contracts, and therefore will incapacitate the country's university system to attract the brightest international APs without paying larger salaries than foreign competing universities are paying. For universities, the choice between advertising a tenure-track job and advertising a teaching job must be part and parcel of the decision about the desired quality of applicants. For APs on the job market, a casual declaration of one's preference between otherwise identical contracts might have consequences even without any irrational prejudices on the part of the employers, simply because this preference is informative about the speaker's ability.

\section{Conclusion}

One criticism of the tenure system is that it promotes mediocrity, by removing the administrators' ability to fire underperforming professors. Here I argue that tenure-track contracts are more attractive to more able APs, others being equal, thus improving the ability distribution of the incoming faculty in schools which offer tenure contracts. This complements the usual arguments for or against tenure, which mostly concentrate on the behavior of tenured faculty.

\section{References}

Alchian, A. A. (1953). Private property and the relative cost of tenure. In P. D. Bradley (Ed.), The Public Stake in Union Power, pp. 350-371. University of Virginia Press: Charlottesville.

Brown, Jr, W. O. (1997). University governance and academic tenure: a property rights explanation. Journal of Institutional and Theoretical Economics 153(3), 441-461. 
Carmichael, H. L. (1988). Incentives in academics: why is there tenure? The Journal of Political Economy 96(3), 453-472.

Cater, B., B. Lew, and M. Pivato (2015). The efficiency of tenure contracts in academic employment. Technical report, Trent University.

Ceci, S. J., W. M. Williams, and K. Mueller-Johnson (2006). Is tenure justified? An experimental study of faculty beliefs about tenure, promotion, and academic freedom. Behavioral and Brain Sciences 29(6), 553-569.

Ginsberg, B. (2011). The Fall of the Faculty. Oxford University Press, USA.

Jones, B., E. Reedy, and B. A. Weinberg (2014). Age and scientific genius. Technical report, National Bureau of Economic Research.

Kahn, C. and G. Huberman (1988). Two-sided uncertainty and "up-or-out" contracts. Journal of Labor Economics 6(4), 423-444.

Machlup, F. (1964). In defense of academic tenure. AAUP Bulletin 50(2), 112-124.

McPherson, M. S. and G. C. Winston (1983). The economics of academic tenure: a relational perspective. Journal of Economic Behavior \& Organization 4 (2), 163-184.

Oster, S. M. and D. S. Hamermesh (1998). Aging and productivity among economists. Review of Economics and Statistics 80(1), 154-156.

Premeaux, S. R. (2012). Tenure perspectives: Tenured versus nontenured tenure-track faculty. Journal of Education for Business 87(2), 121-127.

Waldman, M. (1990). Up-or-out contracts: A signaling perspective. Journal of Labor Economics 8(2), 230-250. 